\title{
Designing a Sophomore Materials Science Laboratory Course Centered on Sustainability
}

Dr. Nancy Ruzycki, University of Florida

Dr. Nancy Ruzycki, is the Director of Undergraduate Laboratories and Faculty Lecturer within the Department of Materials Science and Engineering at the University of Florida Herbert Wetheim College of Engineering. Her focus is on developing curriculum based on best practices for students in engineering and physics. 


\section{Design of a Sophomore Materials Sciences Laboratory Centered on Sustainable Design.}

This paper discusses the design and creation of a sophomore materials science laboratory at the University of Florida (UF) centered on Sustainable Materials and Design. The curriculum committee for the department examined course progression and determined a need for a sophomore laboratory aligned with the Introduction to Materials Science and Engineering course. This paper looks at how the laboratory curriculum was developed by the author to meet departmental needs, as well as a design for student learning through inclusion of research based best practices aligned with ABET criteria. The course explores the materials tetrahedron for metal, ceramics, polymers, composites, centered on the theme of sustainability and engineering design, matched to engineering challenges for societal benefit. The course uses case studies, Granta CES software, laboratory and design activities, with selected readings to provide relevance for core concepts in materials science early in student's academic career. The goal of this paper is to provide a model of how other universities can design laboratories for students, aligning best practices with departmental goals.

\section{Background}

A 2008 report from the Workshop on Materials Science and Materials Engineering Education sponsored by the National Science Foundation September 18-19, 2008, promoted changes for undergraduate programs in materials science ${ }^{1}$ :

"To attract more students to the discipline, materials programs should change the message used to engage prospective undergraduates. The discipline is an enabling one and one that has the potential to provide technological solutions to critical societal issues.

This type of message needs to be used to excite students about opportunities in the field."

Materials Science has a long history paralleling the development of civilization ${ }^{2}$. In early stages of human civilization, natural materials were developed into tools for survival. With the advent of metallic ages, humans utilized materials to make tools and ornaments that advanced living conditions and allowed for advancement of knowledge. Critical to human advancement was the ability of early people to select a material based on considerations of properties needed, availability, workability and performance in application. Early human advancement was tied to the ability of humans to understand the materials tetrahedron and apply it to find new materials having desirable properties for some application.

Despite this call from NSF, and the aligned history of human civilization and materials, there are few university MSE departments ${ }^{3}$ that offer students coursework that combine societal aspects and engineering concepts in a laboratory setting. Engineering is a professional practice that exists to solve societal problems, and having an understanding of how materials sciences is woven into technological advancements to solve human problems is essential to development of a well- rounded engineer, and aligned to the ABET Criteria, especially for $c \& h$-j for design, contemporary issues, and social context. 
Laboratories are a natural fit for coursework combining development of engineering practices and skills aligned with core content theories. Research indicates engineers "learn by doing"3-7, and that laboratory experiences are critical to development of professional engineers. While there are variations in objectives for laboratory in the research literature, an approach taken by Ma and Nickerson ${ }^{7}$, who conducted a literature review on laboratory objectives and then aligned them to ABET objectives will be used here as a frame for discussion. It is easy using this frame to connect and extend the original work ${ }^{7}$ to ABET goals for 2015 as shown in Table 1. This revised frame was used by the author in the development of the sophomore laboratory at the University of Florida.

\begin{tabular}{|c|c|c|}
\hline Laboratory Goals & ABET Goals (2006) & ABET Goals 2015 \\
\hline $\begin{array}{l}\text { Conceptual } \\
\text { understanding }\end{array}$ & $\begin{array}{l}\text { Illustrate concepts and } \\
\text { principles }\end{array}$ & $\begin{array}{l}\text { (a) an ability to apply knowledge } \\
\text { of mathematics, science, and } \\
\text { engineering } \\
\text { (e) an ability to identify, } \\
\text { formulate, and solve engineering } \\
\text { problems } \\
\text { (k) an ability to use the } \\
\text { techniques, skills, and modern } \\
\text { engineering tools necessary for } \\
\text { engineering practice. }\end{array}$ \\
\hline Design Skills & $\begin{array}{l}\text { Ability to design and } \\
\text { investigate } \\
\text { Understand the nature of } \\
\text { science } \\
\text { (scientific mind) }\end{array}$ & $\begin{array}{l}\text { (b) an ability to design and } \\
\text { conduct experiments, as well as } \\
\text { to analyze and interpret data } \\
\text { (c)an ability to design a system, } \\
\text { component, or process to meet } \\
\text { desired needs within realistic } \\
\text { constraints such as economic, } \\
\text { environmental, social, political, } \\
\text { ethical, health and safety, } \\
\text { manufacturability, and } \\
\text { sustainability }\end{array}$ \\
\hline Social Skills & $\begin{array}{l}\text { Social skills and other } \\
\text { productive team behaviors } \\
\text { (communication, team } \\
\text { interaction and problem } \\
\text { solving, leadership) }\end{array}$ & $\begin{array}{l}\text { (d) an ability to function on } \\
\text { multidisciplinary teams } \\
\text { g) an ability to communicate } \\
\text { effectively }\end{array}$ \\
\hline Professional Skills & $\begin{array}{l}\text { Technical/procedural skills } \\
\text { Introduce students to the world } \\
\text { of scientists and engineers in } \\
\text { practice } \\
\text { Application of knowledge to } \\
\text { practice }\end{array}$ & $\begin{array}{l}\text { (f) an understanding of } \\
\text { professional and ethical } \\
\text { responsibility } \\
\text { (h) the broad education necessary } \\
\text { to understand the impact of } \\
\text { engineering solutions in a global, } \\
\text { economic, environmental, and } \\
\text { societal context }\end{array}$ \\
\hline
\end{tabular}




\begin{tabular}{|l|l|l|}
\hline & $\begin{array}{l}\text { (i) a recognition of the need for, } \\
\text { and an ability to engage in life- } \\
\text { long learning } \\
\text { (j) a knowledge of contemporary } \\
\text { issues }\end{array}$ \\
\hline
\end{tabular}

Table 1: Updated Laboratory Goals ${ }^{7}$ re-aligned to ABET 2015.

\section{Sustainable Teaching and Materials Science Programs}

Most materials scientists and engineers would agree that materials are central to creating a sustainable environment. Many universities are starting certificate programs in sustainability with coursework sprinkled across departments, including MSE departments. While several materials sciences departments offer coursework for students aligned with principles of sustainability, few offer laboratory programs aligned with sustainability. A 2012 paper in the MRS Bulletin by Lesar, Chen and Apelian describe how sustainability was woven into coursework at Iowa State, California Polytechnic, and Worcester Polytechnic ${ }^{8}$. While all three universities provided curriculum infusing concepts of sustainable development and the role of materials in a sustainable environment, only California Polytechnic linked it with a project based learning opportunity for students in their freshman year ${ }^{8}$. In many courses using a theme of sustainability, emphasis is placed on learning and using green design principles, methods, tools and materials. Example activities include life cycle assessment, eco-efficiency and ecoeffectiveness. Generally a systems perspective is employed to focus on material and energy flows over a complete product life cycle.

At University of Florida students may major or minor in sustainability studies, and courses can receive a certification of alignment from the Office of Sustainability if their syllabus meets standards set by the department of sustainability studies. This includes incorporation of sustainability practices, including ethics and design. Once a course receives this designation, students within the home department can use this course towards their minor in sustainability. As part of this process, the author attended a week long workshop offered by the Office of Sustainability which provided cross disciplinary faculty with the resources and interdisciplinary interactions to begin incorporating sustainability into their courses. Currently, the only sustainability courses offered at within the College of Engineering are within Engineering School of Sustainable Infrastructure and the Environment, entitled "Green Engineering and Design for Sustainability" it is a 4000 level course for upperclassmen.

\section{Sophomore Laboratories}

Many MSE departments offer laboratories at the sophomore level including MIT, Clemson, Cornell, Rochester and University of Arizona. These laboratories are designed to give students hands-on experience with concepts developed in the lecture course, generally the "Introduction to Materials Science and Engineering”. A survey of university department syllabi found the majority of sophomore laboratories at these universities to be focused on a few techniques and tools, mainly related to mechanical behavior of materials. In the survey undertaken, no university material science departments were found to offer a course related to sustainable materials. 
Within the MSE Department at UF, laboratories are central to the MSE student experience. As part of an ongoing redesign of curriculum within the department, in 2013 the Junior Laboratory courses were redesigned to support the core content courses that all MSE students take in their junior year. Additionally, the laboratory coursework was designed to highlight the Structureprocessing-properties relationships and characterization aspects of materials engineering. In the senior year, students take specialty labs based on their area of interest. Currently the department offers senior laboratories in Polymer Processing, Metal Processing, Ceramic Processing and Electronic Device Processing. The senior experience for laboratories is focused on the processing, optimization and design aspects of materials sciences.

As part of the redesign of the laboratories, courses that were "bundled" with laboratory components (i.e. a four credit polymer processing class plus lab) were unbundled by the curriculum committee to produce a stand-alone 3 hour lecture course, and a 1 hour student laboratory. By doing this, an additional credit hour was found to be available for a new course. Below is a snapshot of how the sophomore laboratory will fit into a student's schedule. The one credit laboratory class will be a two hour meeting once a week. It is anticipated there will be 5060 students in the course, and sections will be fifteen students or less each, allowing for cooperative groupings of students.

\begin{tabular}{|c|c|c|}
\hline Semester 3 & & Credits \\
\hline $\begin{array}{l}\text { EIN } 4354 \text { Engineering Economy (3) or } \\
\text { MAN } 3025 \text { Principles of Management (4) or } \\
\text { MAR } 3023 \text { Principles of Marketing (4) }\end{array}$ & & $3-4$ \\
\hline EMA 3010 Materials & & 3 \\
\hline MAC 2313 Analytic Geometry and Calculus 3 (GE-M) & & 4 \\
\hline PHY 2048 Physics with Calculus 1 (State Core GE-P) & & 3 \\
\hline PHY 2048L Physics with Calculus 1 Laboratory (GE-P) & & 1 \\
\hline \multirow[t]{2}{*}{ Computer programming course (COP 2271 or see advisor for approved list) } & & 2 \\
\hline & Total & $16-17$ \\
\hline Semester 4 & & Credits \\
\hline EGM 2511 Engineering Mechanics: Statics & & 3 \\
\hline EMA 3000L Sophomore Materials Lab & & 1 \\
\hline EMA 3011 Fundamental Principles of Materials & & 3 \\
\hline EMA 3800 Error Analyses and Optimization Methodologies in Materials Research & & 3 \\
\hline MAP 2302 Elementary Differential Equations & & 3 \\
\hline PHY 2049 Physics with Calculus 2 & & 3 \\
\hline \multirow[t]{2}{*}{ PHY 2049L Physics with Calculus 2 Laboratory } & & 1 \\
\hline & Total & 17 \\
\hline
\end{tabular}

Figure 2: Student Catalog for 2016 MSE students for sophomore year at the University of Florida.

\section{Sophomore Laboratory Design}

Once the course was approved for the catalog by the University Curriculum Committee, the course content could be further developed. Since the junior year focuses on characterization, and the structure - processing - properties relationships, and the senior year on processing and optimization, a natural fit for the sophomore laboratory would be structure -properties 
relationships, with a theme of sustainable materials design. This would allow students to conduct design work earlier in their engineering development, and to tie design to content from the introductory materials coursework.

The idea of doing engineering design early in a student's curriculum is well established ${ }^{9-12}$, and many universities are currently implementing cross disciplinary freshman design experiences. It was also established by literature that senior design behavior has tended to be more sophisticated than freshman design behavior and seniors tended to produce higher quality design solutions than freshman when solving the same type of design behavior ${ }^{12}$. For the implementation of the sophomore laboratory at UF, this was taken into account in the design of the laboratory curriculum. While allowing sophomore students to design using sustainable principles, the design projects would be closely aligned to the core content knowledge they were learning during their sophomore year in order to allow them to apply this knowledge directly in context. This is hoped to give sophomore MSE students a richer design experience, and to produce high quality products from the students earlier in their curriculum, and prepare them for a more advanced senior design experience.

Using Table 1 as an initial guide for development, a grid was developed for the course, as seen in Table 2 below.

\begin{tabular}{|l|l|l|l|l|}
\hline $\begin{array}{l}\text { Laboratory } \\
\text { Project }\end{array}$ & $\begin{array}{l}\text { Content aligned with the } \\
\text { Introduction to Materials } \\
\text { Science Course } \\
\text { Conceptual understanding }\end{array}$ & Design Skills & Social Skills & $\begin{array}{l}\text { Professional } \\
\text { Skills }\end{array}$ \\
\hline $\begin{array}{l}\text { Sustainable } \\
\text { Materials } \\
\text { past, present } \\
\text { and future }\end{array}$ & $\begin{array}{l}\text { Structure, properties, } \\
\text { classes of materials, } \\
\text { polymer structures, } \\
\text { Characteristics, } \\
\text { Applications, and }\end{array}$ & $\begin{array}{l}\text { Sustainable } \\
\text { water capture } \\
\text { system using } \\
\text { nature } \\
\text { inspired } \\
\text { design. }\end{array}$ & $\begin{array}{l}\text { Work as part of } \\
\text { a team with } \\
\text { global partner } \\
\text { input. }\end{array}$ & $\begin{array}{l}\text { Contemporary } \\
\text { issues and } \\
\text { materials } \\
\text { solutions to } \\
\text { these problems. }\end{array}$ \\
\hline $\begin{array}{l}\text { Structural } \\
\text { materials for } \\
\text { transportation } \\
\text { solutions }\end{array}$ & $\begin{array}{l}\text { Corrosion, failure analysis, } \\
\text { imperfections in solids, } \\
\text { Mechanical properties of } \\
\text { metals, phase diagrams, } \\
\text { phase transformations, } \\
\text { applications and processing } \\
\text { of metal alloys, composites }\end{array}$ & $\begin{array}{l}\text { Sustainable } \\
\text { materials for } \\
\text { automotive } \\
\text { and } \\
\text { transportation } \\
\text { needs. Design } \\
\text { for upcycled } \\
\text { car parts. }\end{array}$ & $\begin{array}{l}\text { Work as part of } \\
\text { a team with } \\
\text { industry } \\
\text { partner input. }\end{array}$ & $\begin{array}{l}\text { Engineering } \\
\text { solutions in a } \\
\text { global context. }\end{array}$ \\
$\begin{array}{l}\text { Materials for } \\
\text { Healthcare } \\
\text { and Medicine }\end{array}$ & $\begin{array}{l}\text { Diffusion, Magnetism, } \\
\text { Thermal Properties, } \\
\text { degradation, Structure and } \\
\text { properties of Ceramics }\end{array}$ & $\begin{array}{l}\text { Sustainable } \\
\text { materials for } \\
\text { biomaterials } \\
\text { applications }- \\
\text { printable } \\
\text { biomaterials } \\
\text { and magnetic } \\
\text { nanoparticles. }\end{array}$ & $\begin{array}{l}\text { Work as part of } \\
\text { a team with } \\
\text { graduate } \\
\text { student partner } \\
\text { input. }\end{array}$ & $\begin{array}{l}\text { Nerstanding } \\
\text { professional } \\
\text { and ethical } \\
\text { responsibilities. } \\
\text { continued } \\
\text { learning in } \\
\text { order to solve } \\
\text { complex } \\
\text { problems. }\end{array}$ \\
\hline
\end{tabular}




\begin{tabular}{|l|l|l|l|l|}
\hline $\begin{array}{l}\text { Materials for } \\
\text { Energy needs }\end{array}$ & $\begin{array}{l}\text { Electricity, imperfections in } \\
\text { solids, optical properties }\end{array}$ & $\begin{array}{l}\text { Sustainable } \\
\text { materials for } \\
\text { energy- LEDs }\end{array}$ & $\begin{array}{l}\text { Work as part of } \\
\text { a team with } \\
\text { industry } \\
\text { partner input. }\end{array}$ & \\
\hline
\end{tabular}

Table 2: Content Alignment with Laboratory Objectives based on ABET aligned laboratories.

This new frame provides the basis for development of individual activities aligned to best practices. These are shown later in Table 3. Each activity has a first week "kickoff session" where students are introduced to the design challenge and have a speaker, industry "client", or professor to introduce the materials issue aligned with the challenge. Each of these entities becomes an outside resource who helps teams meet constraints and criteria for the project, and to whom students will report design progress in technical reports. Students will complete a prereading assignment prior to the lab, and have selected readings each week that they will need to summarize and report out on in a group style meeting format in order to build and support core content knowledge integration from the Introduction to Materials Science course with societal issues related to the design project.

Students will go through a series of short labs in order to provide technical knowledge, vocabulary and skills for their design challenge. Each laboratory activity is designed as a rotation where students will rotate in small groups to perform the experiments. During these laboratories, emphasis will be placed on the structure-properties relationship for the materials being studied. Students will be drawn back to the core content from their introductory materials course to support their concept development.

Students then enter the design activity phase, where they will design and test materials for desired properties. Students will create and test small prototypes, and test these prototypes using ASTM or experimental standards. Students will analyze their data to share and report to their outside resource. During the design phase students will use the Granta CES pack to screen materials, as well as to determine aspects related to Life Cycle Analysis (LCA) for the production of the materials.

\section{Assessment of Sophomore Laboratory}

Student products are import aspects of laboratory experiences that solidify the design experience for the students, and allow for student assessment. In the sophomore laboratory, student products will be laboratory/design notebooks, design projects \& presentations (oral and written). These products build towards development of an engineering professional capacity through the writing, speaking and communicating in the ways of a professional engineer. Every student product will have a rubric for preparation and scoring, and an exemplar so that students can compare their work to a standard.

For the first year (spring 2017) students will report back through a survey tool currently in development to assess the efficacy of the activities and design project. The curriculum will be refined and pilot-tested over the summer for the next implementation cycle.

\section{Themes for Sophomore Laboratory Activities}


It is envisioned that themes and activities can be changed or strengthened to support student core MSE concepts related to the introductory materials science course, and that the design projects can be changed or aligned to better serve students and department curricular needs based on feedback, as well as in addition to being adjusted for current societal issues, including cuttingedge engineering applications that are not yet described in textbooks. Below are working examples of the way the themes are applied to support core content in the Introduction to Materials Science course, and build design, technical and experimental skills in students.

\begin{tabular}{|c|c|}
\hline \multicolumn{2}{|c|}{ Sustainable Materials past, present and future } \\
\hline Weeks & 4 \\
\hline $\begin{array}{l}\text { Experiments } \\
\text { aligned with } \\
\text { content goals }\end{array}$ & $\begin{array}{l}\text { Porosity of materials. } \\
\text { Density of materials related to structure. } \\
\text { Patterning of polymers for desired properties } \\
\text { Polymer characteristics and properties experiment. } \\
\text { Polymer Crystallinity experiment. } \\
\text { Experiment in surface tension and wetting. }\end{array}$ \\
\hline Techniques/Tools & $\begin{array}{l}\text { Archimedes density, Differential Scanning Calorimetry, Ceramic Processing } \\
\text { and firing, Scanning Electron Microscope, polymer and ceramic templating, }\end{array}$ \\
\hline Design Activity & $\begin{array}{l}\text { Students will use Granta Software to analyze desired materials for testing. } \\
\text { Students will skype with other students to find constraints and environmental } \\
\text { parameters. } \\
\text { Students will test fibers in a fog chamber and refine fibers for retesting. } \\
\text { Students will test materials for water storage }\end{array}$ \\
\hline $\begin{array}{l}\text { Related } \\
\text { Activities }\end{array}$ & $\begin{array}{l}\text { Visit to University Museum of Natural History and tour and discussion with } \\
\text { scientists at the museum. } \\
\text { Skype talks between engineering students in US and in Columbia, Brazil or } \\
\text { Nigeria. } \\
\text { Skype talk with engineers on the Warka Water project }{ }^{13}\end{array}$ \\
\hline $\begin{array}{l}\text { Selected } \\
\text { Readings }\end{array}$ & Selected readings ${ }^{14-18}$ \\
\hline $\begin{array}{l}\text { Assessed Student } \\
\text { Product }\end{array}$ & $\begin{array}{l}\text { Design model and prototype of a water capture system based on nature. } \\
\text { Students will share model with international student partners. }\end{array}$ \\
\hline
\end{tabular}

\begin{tabular}{|l|l|}
\hline Structural materials for transportation solutions \\
\hline Weeks & 4 \\
\hline Experiments & Fiberglass and Carbon fiber layup \\
aligned with & Fiberglass and Carbon fiber mechanical testing \\
content goals & Characteristics of metals and alloys. \\
& Phase and TTT diagrams for alloys. \\
& Failure analysis in materials \\
& Microstructure and metallography \\
& Corrosion testing of metals \\
& Upcycling of materials \\
\hline Techniques/Tools & Scanning Electron Microscope, metallographic techniques, Charpy Impact \\
\hline
\end{tabular}




\begin{tabular}{|l|l|}
\hline & testing, 3 point bending, fatigue testing, tensile testing, Creep \\
\hline Design Activity & $\begin{array}{l}\text { Students will use Granta Software to analyze desired materials for testing. } \\
\text { Students will conduct a LCA for the materials used in the project. } \\
\text { Students use case studies from readings to redesign one of the applications } \\
\text { for upcycling and reuse. } \\
\text { Students will test materials that have been upcycled and recast for properties } \\
\text { meeting design constraints. } \\
\text { Students will test materials for use in light weight cars that can be upcycled } \\
\text { for reuse. }\end{array}$ \\
\hline $\begin{array}{l}\text { Related } \\
\text { Activities }\end{array}$ & $\begin{array}{l}\text { Skype talk between automotive engineers and students. } \\
\text { Skype talks between metals recycler. } \\
\text { Skype talk with metals producer. } \\
\text { On campus demonstration with a light weight car for students to examine for } \\
\text { use of materials. } \\
\text { Tour of on campus SAE race car team facilities. }\end{array}$ \\
\hline $\begin{array}{l}\text { Selected } \\
\text { Readings }\end{array}$ & $\begin{array}{l}\text { Selected readings 19-23 } \\
\text { Assessed Student } \\
\text { Product }\end{array}$ \\
$\begin{array}{l}\text { Design and test materials for use in lightweight cars for strength and ability } \\
\text { to be upcycled. Re-design a car part for a light weight car part that is made } \\
\text { from upcycled material, or can be recovered later for upcycling. Students } \\
\text { will share designs with industry partners. }\end{array}$ \\
\hline
\end{tabular}

\begin{tabular}{|c|c|}
\hline \multicolumn{2}{|c|}{ Materials for Healthcare and Medicine } \\
\hline Weeks & 4 \\
\hline $\begin{array}{l}\text { Experiments } \\
\text { aligned with } \\
\text { content goals }\end{array}$ & $\begin{array}{l}\text { Diffusion of gases through materials, permeability of polymers } \\
\text { Thermal effects on materials structure and properties } \\
\text { Ferro-fluids and properties } \\
\text { Structure and Properties of ceramics } \\
\text { Properties of materials on the nanoscale } \\
\text { pH effect on biomaterials } \\
\text { Biomaterials interfaces } \\
\text { Biomaterials and nanoparticle printing }\end{array}$ \\
\hline Techniques/Tools & $\begin{array}{l}\text { Vibrating sample magnetometer, oxygen sensors, UV-Visible } \\
\text { spectrophotometer. pH measurements, } 2 \& 3 \text { D printing, UV crosslinking of } \\
\text { polymers, AFM }\end{array}$ \\
\hline Design Activity & $\begin{array}{l}\text { Students will use Granta Software to analyze desired materials for testing. } \\
\text { Students will design Inkjet Printing of Flexible Electronics for Body-Worn } \\
\text { Medical Devices }\end{array}$ \\
\hline $\begin{array}{l}\text { Related } \\
\text { Activities }\end{array}$ & $\begin{array}{l}\text { Introductory talk by professors doing materials research with } \\
\text { biomedical/biomaterials applications. }\end{array}$ \\
\hline $\begin{array}{l}\text { Selected } \\
\text { Readings }\end{array}$ & Selected readings ${ }^{24-29}$ \\
\hline $\begin{array}{l}\text { Assessed Student } \\
\text { Product }\end{array}$ & $\begin{array}{l}\text { Design and test materials for use in printing of body worn medical devices. } \\
\text { Students will share design with graduate students and professors through a }\end{array}$ \\
\hline
\end{tabular}


poster session.

\begin{tabular}{|c|c|}
\hline \multicolumn{2}{|c|}{ Materials for Energy Needs } \\
\hline Weeks & 4 \\
\hline $\begin{array}{l}\text { Experiments } \\
\text { aligned with } \\
\text { content goals }\end{array}$ & $\begin{array}{l}\text { Basic Circuit construction and measurement, Data Acquisition using } \\
\text { LabVIEW, I-V of Light-Emitting Diodes, I-V of Photovoltaic Cell, } \\
\text { Determination of wavelength of an infrared LED, Contact resistance, Make a } \\
\text { simple OLED }\end{array}$ \\
\hline Techniques/Tools & Multimeter, power supplies, XRD, SEM, IV characterization \\
\hline Design Activity & $\begin{array}{l}\text { Students will use Granta Software to analyze desired materials for testing } \\
\text { and to do a LCA for the materials used in creating the proposed LED. } \\
\text { Students will design a new color LED. }\end{array}$ \\
\hline $\begin{array}{l}\text { Related } \\
\text { Activities }\end{array}$ & $\begin{array}{l}\text { Introductory talk by professors making LEDs and OLEDs } \\
\text { Weekly Skype talks with industrial engineers making LEDs, and OLEDs. }\end{array}$ \\
\hline $\begin{array}{l}\text { Selected } \\
\text { Readings }\end{array}$ & Selected readings ${ }^{30-34}$ \\
\hline $\begin{array}{l}\text { Assessed Student } \\
\text { Product }\end{array}$ & $\begin{array}{l}\text { Design an LED for a new color not yet produced on the market with an LCA } \\
\text { analysis. } \\
\text { Students will share design with industry partners. }\end{array}$ \\
\hline
\end{tabular}

Table 3: Overview of Laboratory progression aligned to laboratory objectives.

\section{Conclusion}

This paper looks at how laboratory curriculum was developed within the Materials Science and Engineering Department at the University of Florida to support students early in their engineering coursework. The course under development explores the materials tetrahedron for metal, ceramics, polymers, composites, and is centered on themes of sustainability, design, and engineering challenges for societies. The laboratory course is aligned to the Introduction to Materials Science course, and supports core concepts in the course. Within the laboratory, case studies, Granta CES software, laboratory and design activities supported by selected readings are used to provide relevance for the concepts for materials science students early in their academic career, and to incorporate best practices for student learning. Student work will be supported and graded using rubrics and exemplars, and an assessment tool is being developed to provide tuning feedback in order to refine the laboratories in future years.

\section{References:}

1. Bartolo, L. et.al (2008), The Future of Materials Science and Materials Engineering Education, Workshop on Materials Science and Materials Engineering Education, NSF, September 2008.

2. Olson, G. B. (2000). Designing a new material world. Science, 288(5468), 993-998.

3. Feisel, L. D., \& Rosa, A. J. (2005). The role of the laboratory in undergraduate engineering education. Journal of Engineering Education, 94(1), 121-130.

4. Feisel, L.D., and Peterson, G.D.,(2002). The Challenge of the Laboratory in Engineering Education," Journal of Engineering Education, 91(4), 2002, pp. 367-368 
5. Edward, N. S. (2002). The role of laboratory work in engineering education: student and staff perceptions. International Journal of Electrical Engineering Education, 39(1), 11-19.

6. Magin, D., \& Kanapathipillai, S. (2000). Engineering students' understanding of the role of experimentation. European journal of engineering education, 25(4), 351-358.

7. Ma, J., \& Nickerson, J. V. (2006). Hands-on, simulated, and remote laboratories: A comparative literature review. ACM Computing Surveys (CSUR), 38(3), 7.

8. LeSar, R., Chen, K. C., \& Apelian, D. (2012). Teaching sustainable development in materials science and engineering. MRS bulletin, 37(04), 449-454

9. Sheppard, S., \& Jennison, R. (1997). Freshman engineering design experiences and organizational framework. International Journal of Engineering Education, 13, 190-197.

10. Atman, C. J., Chimka, J. R., Bursic, K. M., \& Nachtmann, H. L. (1999). A comparison of freshman and senior engineering design processes. Design Studies, 20(2), 131-152.

11. Dally, J. W., \& Zhang, G. M. (1993). A freshman engineering design course. Journal of Engineering Education, 82(2), 83-91.

12. Atman, C. J., Cardella, M. E., Turns, J., \& Adams, R. (2005). Comparing freshman and senior engineering design processes: an in-depth follow-up study. Design studies, 26(4), 325357.

13. http://www.warkawater.org/design.

14. Shiva, V. (2002). Water wars. Zed: London.

15. Ashby, M. F. (2012). Materials and the environment: eco-informed material choice.

Elsevier.

16. Parker, A.R. and Lawrence, C.R., 2001. Water capture by a desert beetle. Nature, 414(6859), pp.33-34.

17 Zheng, Y., Bai, H., Huang, Z., Tian, X., Nie, F. Q., Zhao, Y. \& Jiang, L. (2010). Directional water collection on wetted spider silk. Nature, 463(7281), 640-643.

18. Vollrath, F., \& Knight, D. P. (2001). Liquid crystalline spinning of spider silk. Nature, 410(6828), 541-548.

19. Das, S. (2001). The cost of automotive polymer composites: a review and assessment of DOE's lightweight materials composites research (p. 47). Oak Ridge, TN: Oak Ridge National Laboratory.

20. Joost, W. J. (2012). Reducing vehicle weight and improving US energy efficiency using integrated computational materials engineering. Jom, 64(9), 1032-1038.

21. Skszek, T. W., Zaluzec, M., Conklin, J., \& Wagner, D. (2015).The Multi Material Lightweight Vehicle (MMLV) project. SAE Technical Book.

22. Smith, K., \& Zhang, Y. (2015). MMLV: Corrosion Design and Testing (No. 2015-01-0410). SAE Technical Paper.

23. Plourde, L., Azzouz, M., Wallace, J., \& Chellman, M. (2015). MMLV: Door Design and Component Testing (No. 2015-01-0409). SAE Technical Paper.

24. Campbell, P. G., \& Weiss, L. E. (2007). Tissue engineering with the aid of inkjet printers. Expert opinion on biological therapy, 7(8), 1123-1127.

25. Ringeisen, B. R., Spargo, B. J., \& Wu, P. K. (Eds.). (2010). Cell and organ printing. Springer Science \& Business Media.

26. Institute of Medicine (US) Roundtable on Environmental Health Sciences, Research, and Medicine; Goldman L, Coussens C, editors. Implications of Nanotechnology for Environmental 
Health Research. Washington (DC): National Academies Press (US); 2005. 2, The Promise of Nanotechnology. Available from: http://www.ncbi.nlm.nih.gov/books/NBK21034/

27. Koch, L., Kuhn, S., Sorg, H., Gruene, M., Schlie, S., Gaebel, R., ... \& Vogt, P. M. (2009). Laser printing of skin cells and human stem cells. Tissue Engineering Part C: Methods, 16(5), 847-854.

28. Singh, M., Haverinen, H. M., Dhagat, P., \& Jabbour, G. E. (2010). Inkjet printing — process and its applications. Advanced materials, 22(6), 673-685.

29. Andrew, J. S., Starr, J. D., \& Budi, M. A. (2014). Prospects for nanostructured multiferroic composite materials. Scripta Materialia, 74, 38-43.

30. Qian, L., Zheng, Y., Xue, J., \& Holloway, P. H. (2011). Stable and efficient quantum-dot light-emitting diodes based on solution-processed multilayer structures. Nature photonics, 5(9), 543-548.

31 Prashant K. Sarswat, Michael L. Free. Light emitting diodes based on carbon dots derived from food, beverage, and combustion wastes. Phys. Chem. Chem. Phys., 2015; 17 (41): 27642 DOI: $10.1039 / \mathrm{c} 5 \mathrm{cp} 04782 \mathrm{j}$

33. Schroder, D. K., \& Meier, D. L. (1984). Solar cell contact resistance-a review. Electron Devices, IEEE Transactions on, 31(5), 637-647.

34.Vázquez-Córdova, S., Ramos-Ortiz, G., Maldonado, J. L., Meneses-Nava, M. A., \& BarbosaGarcía, O. (2008). Simple assembling of organic light-emitting diodes for teaching purposes in undergraduate labs. Revista mexicana de física E, 54(2), 146-152. 